Since the pablication of Dr. Beatson's case Mr. Stanley Boyd and Mr. Watson Cheyne have reported cases of oöphorectomy for mammary cancer, but it is not stated in their reports that thyroid extract was given. Thyroid extract has very powerfal effects upon the body, and I think Dr. Beatson's practice cannot be said to have been followed if thyroid extract has not been given. Cases treated by oöphorectomy without thyroid extract do not justify a conclusion as to the uselessness of oöphorectomy plus tbyroid extract. My reason for combining oöphorectomy with thyroid extract was simply that Dr. Beatson's successful case was treated in that way. The explanation of the benefit which seems to me the probable one is that based on the protozoon theory of cancer-that the withdrawal of the ovarian secretion, coupled with the presence of an excess of the thyroid secretion, makes the tissces of some persons a less fir food for the cancer protozoon.

I have since treated some cases of uterine and vaginal cancer by oöphorectomy and thyroid extract, bat the results are not yat complete enough for publication.

Harley-street, W.

\section{THE LOSS OF SEXUAL POWER IN TABES DORSALIS.}

BY R. CUNYNGHAM BROWN, M.D. DURH.,

CLINICAL ASSISTANT TO THE NATIONAT HOSPITAL FOR THE PARALYSED AND EPILEPTIC, QUEEN-SQUARE; IAATE JUNIOR HOUSE SURGEON AND SENIOB ASSISTANT HOUSE SURGEON, HODDERSFIFID INTIRMARY.

Loss of sexual power is one of the most constant disturbances of function encountered in tabes, being present in at least 70 per cent. of cases of over two years' duration. Leimbach ${ }^{1}$ found it present in 5825 per cent. of all cases of whatever duration, and in 15.54 per cent. it was one of the earliest symptoms of the disease. Before investigating, however, this distarbance of function it may be well to glance at the normal mechanism. Erection is a complex process largely reflex in nature, having for its afferent limb fibres passing from the glans penis and penis to the upper sacral and lower lumbar cord and for its efferent limb fibres passing from the cord to branches supplying the pudic and dorsal arteries of the penis and the transversus peringi and balbo-cavernosus muscles. Erection therefore depends partly on the presence of afferent stimuli ascending from the penis, but may also be initiated or inhibited by cerebral impulses. Ejaculation is an act more dependent than erection on the presence of afferent stimuli. The afferent impulses in this case also come mainly from the glans penis. The efferent impulses are spread over a larger area than in the case of erection, effecting peristaltic contraction of the muscles of the epididymis, vas deferens, and prostate, and later rhythmic contractions of the levator ani, sphincter ani, constrictor urethræ, \&c.

Tabes being mainly, if not entirely, a disease of the mechanism subserving the production and transmission of afferent impalses, it is to be expected that the loss of sexual power in tabes should be found to be due to the diminution or loss of those afferent impalses concerned in the act. The larger contention, that tabes is entirely a disease of the mechanism subserving the production and transmission of afferent stimuli, is outside the range of this paper, but in this connexion Dr. Warrington's paper $^{2}$ on the effect of section of the posterior roots on the cells of the anterior horn and that of $\mathrm{Dr}$. Schaffer ${ }^{3}$ on the changes in the cells of the anterior horn in tabes are of great value. Clinical experience, however, shows clearly the part which loss of afferent stimuli plays in the production of loss of sexual power. of 12 cases of tabes taken at random 2 were women and not examined from this point of view. Of the remaining 10, 8 had suffered from tabes for a period of two years or more, and in these loss of sexual power was present in 6 . None of them were old men, only one being ove: forty years of age. Now in every one of these 6 cases in which there was loss of sexual power there was absolnte analgesia of the glans and comparative or absolute analgesia

1 Leimbach : Deutsche Zeitschrift für Nervenheilkunde, 1895.

2 Warrington: A paper read before the Liverpool Medical Institution on April 21st, 1898 . THE LaNCET, April 30th, 1898

3 Sohaffer: Monatsschrift für Psychiatrie und Neurologie, Berlin, 1888, Band ij., S. 61-98. of the rest of the penis. 4 of these had in addition comparative loss of tactile sensibility in the penis and glans, but in the other 2 tactile sensibility was normal. Further, in the 4 cases in which there was no loss of sexual power there was no affection of sensibility of the penis or glans. These figures are very significant and indicate very clearly that the alteration in sexual power is closely related to the diminution or loss of afferent impulses from the skin and possibly deeper structures of the glans and penis.

The loss of sexual power is gradual in onset and exists in proportion to the amount of analgesia of the glans. In the majority of cases examined, also, the condition might be described as belonging to one of two stages: (1) that of loss or diminution of voluntary sexual power with persistence of involuntary erection and emission; and (2) loss of both voluntary sexual power and involuntary emission. In the first stage analgesia of the glans alone or accompanied by diminished tactile sensibility is present, but the testicles are not atrophied and testicular sensation is present. In the second stage there are in addition atrophy of the testicles and loss of testicular sensation. The first stage passes gradually into the second, but a considerable time may elapse before complete loss of gexual power is established. In one case, three years after the loss of voluntary power, erection and emissions of purely cerebral origin occurred with regalar frequency. This persistence of emission of cerebral origin shows that the efferent paths may remain capable of function long after the reflex process is impossible and indicates the afferent nature of the lesion. As to the site of the morbid processes at work it is impossible to speak with certainty at this stage. Gumpertz, ${ }^{4}$ however, has demonstrated changes very early in tabes in the peripheral nerve structures, and it is, at any rate, possible that this, as well as other symptoms of tabes, is due to disease commencing not in the posterior spinal ganglia or in the posterior root at its junction with the cord, but in the extremely peripheral nerve structures subserving the production and transmission of afferent impulses.

Chancery: lane, W.C.

\section{VITALITY :}

\section{AN APPEAL, AN APOLOGY, AND A CHALLENGE ADDRESSED TO BROTHER PRACTITIONERS.$$
\mathrm{BY}
$$

\section{LIONEL S. BEALE.}

(Continued from page 1050.)

$\triangle M O N G$ the untenable propositions enumerated not the least extravagant is that in which the growth of living things is classed with the process of accretion or aggregation in the non-living world. Only watch the gradual living growth as seen by all in the little child. Can the faintest analogy be pointed out between this vital growth and any inorganic process whatever? Think of the increase of the several complex tissues, for example, in the arm or in a finger. As the member grows in length, do not the nerve plexuses distributed to the peripheral parts become separated by a gradually increasing distance from the nerve centres, and does not this change occur not only without interraption but at the same time that steady improvement in nerve action is taking place? Do not new tissue formations, new growth, and new nerve action all actively proceed and simultaneously? How, then, can such phenomena be cansed, directed, and regulated by physics or swayed by chemistry?

If we study but a small particle of the growing tissnes in properly prepared microscopical specimens we shall find millions of minute bioplasts among the tissues formed daring growth-the vital phenomena and tissue formation and action proceeding with great regularity during the whole period; not only so, but evidence of anticipation of a fature condition, of preparation for further growth and arrangement of tissue. Thus the complete development and action of the several tissues and their continued and healtby action are provided for during youth, adolescence, maturity, old age, decrepitude, ap to death-one stage so gradually passing 4 Gumpertz': Berliner Medicinische Wochenschrift, 1898, Band xxxv." p. 62 . 